\title{
ZAKOMPONOVÁNÍ RIZIKA LIKVIDITY DO MODELU VALUE AT RISK
}

\author{
Michal Polák
}

\section{Klíčová slova:}

Hodnota v riziku upravená o náklady likvidace; Bid - ask spread (tržní rozpětí); náklady na likvidaci; náklady, cenový dopad.

\section{Key words:}

Liquidity Adjusted Value-at-Risk, Bid-Ask Spread, Liquidity cost, Costs, Price Impact.

\begin{abstract}
Abstrakt
Hlavním cílem článku je poukázat na způsoby začlenění rizika likvidity do základního modelu VaR. Riziko likvidity v modelu VaR je zakomponováno prostřednictvím nákladů na likviditu ve formě bid - ask spreadu. Hlavní myšlenkou přístupu začleňovaní exogenního rizika likvidity do modelu je připočítaní maximální možné změny tržního rozpětí k maximální možné ztrátě na středové hodnotě aktiva (mid cena) při určitém stupni pravděpodobnosti. Změny tržního rozpětí chápeme jako samostatnou náhodnou veličinu, která je definovaná střední hodnotou a rozptylem a pravděpodobnostním rozdělením. V modelech se často uvažuje jenom s normálním rozdělením, což může zkreslovat reálnou hodnotu v riziku, hlavně na trzích s nelikvidními aktivy. Důležitým faktorem u rizika likvidity je i časový faktor, který chápeme jako riziko likvidity v důsledku variability tržního rozpětí během doby likvidace aktiva. Z uvedených metod kvantifikace také platí, čím je delší doba do likvidace aktiva, tím je i hodnota VaR vyšší.
\end{abstract}

\begin{abstract}
The main aim of the article is to point out ways of integrating liquidity risk into basic VaR model. Liquidity risk in the VaR model is incorporated through the cost of disposal in the form of a bid - ask spread. The main idea of the approach incorporating exogenous liquidity risk in the model is to add maximal possible changes of the market range to maximum possible loss of assets price (mid price) for a certain degree of probability. Changes in the market range is understood as an independent random variable, which is defined by the mean and variance and probability distribution. The models are often considered only the normal distribution, which can distort the Vaule at risk, especially in markets with illiquid assets. An important factor in the liquidity risk is the time factor, which is understood as liquidity risk due to the variability of the market range over the liquidation of assets.From those methods of quantification, is known, that, the longer time of liquidation asset, the higher is VaR.
\end{abstract}

\section{Úvod}

Likvidní riziko - včetně tržního a kreditního rizika - hrálo významnou roli v oblasti risk managementu nejen během krize, ale i mimo ni. Poslední dobou se hodně mluví o tržním riziku, tzv. riziku změny tržních cen a kreditním riziku (riziku pravděpodobnosti defaultu protistrany). Opomíjí se význam a důležitost likvidního rizika v portfoliu institucí, kde značnou část tvoří právě nelikvidní aktiva. Mezi základní typy rizika likvidity patří riziko tržní likvidity a riziko finanční likvidity. V článku se budeme zabývat rizikem tržní likvidity. 
Tento typ rizika vnímáme jako schopnost účastníka trhu realizovat finanční transakci s daným instrumentem, bez výrazného ovlivnění ceny a porušení podmínek na trhu.

Řízení tržních rizik je za normálních podmínek tradičně zaměřeno na distribuci změny hodnoty portfolia vyplývající z pohybů rizikových faktorů. Jinými slovy logaritmem cenových změn finančních instrumentů a jiných podkladových aktiv. Tržní riziko je hlavním aspektem ve výpočtu hodnoty v riziku (VaR). Problémem tradičních modelů VaR (Morgan 1996), je abstrahovaní od tržního rizika likvidity, které chápeme jako rozdíl mezi bid a ask cenou, tzv. bid-ask spreadem. Klasické modely používají změny středových cen, což představuje $\mathrm{v}$ prrípadě určitých nelikvidních aktiv a trhů podstatné zanedbání rizika. Jednoduchým zakomponováním likvidního rizika tzv. nákladů na likvidaci finančního aktiva do modelu VaR, lze $\mathrm{v}$ případech nelikvidních expozic v portfoliu významným způsobem ovlivnit hodnotu VaR. V některých případech nelikvidních pozic v portfoliu je rozdíl oproti původnímu VaR v rozmezí i 20-30 \% (Bangia et al., 1999).

V první kapitole je krátce shrnuta definice základního modelu VaR a jeho způsoby výpočtu. Druhá kapitola se věnuje likvidnímu riziku a základnímu dělení z pohledu tržního rizika likvidity na exogenní a endogenní riziko likvidity. Exogenní je mimo kontrolu účastníka trhu, respektive obchodníka, kdežto endogenní riziko likvidity závisí na objemu obchodované pozice na trhu - tzn., že ho obchodník je schopen ovlivnit. V posledních třech kapitolách se věnuji kvantifikaci a zakomponování exogenního rizika likvidity do VaR kvantifikovaného pomocí parametrické metody, konkrétně variačně kovarianční metody.

\section{Základní koncept modelu VaR}

Hodnota v riziku (dále jen VaR) definuje maximální možné ztráty, které mohou vzniknout za předem definované období s určitým stupněm pravděpodobnosti. VaR také určuje hodnotu, která nebude překročena za určité období s danou pravděpodobností.

Existují dva způsoby určení VaR, a to relativní, kde ztráta je určena jako procento z dané hodnoty aktiva či portfolia, nebo absolutní, kde ztráta je porovnávána s počáteční hodnotou aktiva nebo portfolia. Jorion (2001) uvádí, když $W_{\mathrm{o}}$ je jako počáteční hodnota, tak potom hodnota na konci období je rovna $W=W_{0}(1+R)$, výnos $\mathrm{R}$ je definován střední hodnotou $\mathrm{E}(\mathrm{R})=\mu$ a rozptylem $\mathrm{V}(\mathrm{R})=o^{2}$. Nejhorší možný výnos za určitého stupně pravděpodobnosti je definován jako $\mathrm{R}^{\prime}$, potom relativní a absolutní $\mathrm{VaR}$, je definován výrazem:

$$
\begin{aligned}
V a R= & E(W)-W^{*}=-W_{0}\left(R^{\prime}-\mu\right) \\
& V a R^{*}=W_{0}-W^{*}=-W_{0} R^{*}
\end{aligned}
$$

Kde $W^{*}=W_{0}\left(1+R^{\prime}\right)$ je současná hodnota nejhorší možné varianty hodnoty portfolia. Podle definice uvedené výše chceme definovat nejhorší možnou hodnotu portfolia, která nebude př́kročena s určitým stupněm pravděpodobnosti $P\left(\omega \leq W^{*}\right)=1-\varepsilon$, kde c je stupeň spolehlivosti, který uvádí procento, dle kterého se budou splňovat očekávání. W' definuje kvantil rozdělení hodnoty portfolia. Když přepokládáme normální rozdělení výnosů tak nejhorší možný výnos z portfolia je daný vztahem:

$$
P(R<R)=P\left(Z<\frac{R^{*}-\mu}{\sigma}\right)=1-c
$$


Kde $Z=\frac{R^{*}-\mu}{\sigma}-N(0,1)$ - následně potom platí $R^{*}=\mu+\alpha \sigma$, kde $\alpha<0$, je kvantil standardního normálního rozdělení.

Když použijeme vztah (1) a (2), tak relativní VaR je rovný $V a R-\alpha \sigma W_{0}$ a absolutní VaR, $\mathrm{VaR}^{\prime}=-(\sigma \sigma[+\mu) W]_{0}$.

Mezi nejnovější metody výpočtu hodnoty VaR patří:

1) Parametrické metody (RiskMetrics a GARCH${ }^{1}$ )

2) Neparametrické metody (Historická simulace a hybridní model)

3) Poloparametrické metody (Teorie extremních hodnot a $\mathrm{CVaR}^{2}$ )

4) Monte Carlo simulace (metoda založena na simulaci náhodného procesu proměnných do modelu)

Přestože VaR představuje poměrně jednoduchou a jasnou koncepci, jeho kvantifikace představuje složitý statistický problém. Hlavním rozdílem mezi jednotlivými metodami je způsob odhadu rozdělení změn ceny aktiv a tím hodnoty portfolia.

\section{Riziko likvidity}

Riziko likvidity je jedním z hlavních zdrojů finančních rizik, které má významný dopad na výnosy a ceny finančních instrumentů, jak již historie u LTCM ${ }^{3}$ ukázala. Dle Joriona (2011) problémy nastávají prodejem aktiv, který je nutný v důsledku potřeby řízení likvidity. Krize důvěry ve finanční instituce se nastartovala podřízenými ztrátami (tzv. subprime loses) a vyvrcholila pádem Lehman Brothers. Mnoho věřitelů odmítlo ponechat své investice ve finančních institucích, což přivodilo problémy s jejich financováním a následně nutnost hledat alternativní zdroje financování (likvidity) na trhu za horší cenu. Za prríčinu můžeme označit nelikvidní trh nebo nelikvidní aktivum. Nedostatek likvidity může způsobit pád instituce, i když je technicky solventní (tj. když je tržní hodnota aktiv vyšší než tržní hodnota pasiv) (Jorion, 2011). U komerčních bank je podstatné riziko likvidity způsobeno nevyvážením splatnosti mezi jejich aktivy (dlouhé splatnosti půjček) a jejich pasivy (vklady od obyvatelů, dluhy). Ztráta důvěry banky nebo instituce může vést $\mathrm{k}$ požadavku vyplácení peněz $\mathrm{v}$ krátkém období. I když banka má dostatek aktiv na pokrytí svých závazků, v případě nedostatečně rychlé likvidity a následného prodeje aktiv za netržní cenu může zpo̊sobit problémy s pokrytím závazků banky. Obecně likviditu na trhu definujeme jako schopnost účastníků trhu vykonat obchod jakéhokoliv objemu, bez významného dopadu na cenu. Likvidita může být

\footnotetext{
${ }^{1}$ Generalized autoregressive conditional heteroskedasticity (GARCH, Bollerslev. 1986)) model

${ }^{2}$ Conditional Value at Risk $(\mathrm{CVaR})$ je metodou převážně používanou na určení míry extremního rizika. Tento model dokáže kvantifikovat VaR i za hranice klasického VaR a také je koherentní mírou rizika. Koherentní míra rizika má následující čtyři vlastnosti pro libovolné dvě náhodné proměnné $\mathrm{X}$ a $\mathrm{Y}: 1)$ subadivitu, $\delta(\mathrm{X}+\mathrm{Y})<=$ $\delta(\mathrm{X})+\delta(\mathrm{Y}), 2)$ monotónnost $\delta(\mathrm{X})<=\delta(\mathrm{Y}), 3)$ homogenitu, $\delta(\mathrm{X}) £ \delta(\mathrm{Y}), 4)$ ivarianci. Pro každé c $\boldsymbol{E} \mathrm{R}+$ platí $^{\delta}(\mathrm{c}+\mathrm{X})=\mathrm{c}+\hat{\delta}(\mathrm{X})$ viz (ARTNER et al., 1999).

${ }^{3}$ Long-Term Capital Management L.P. (LTCM) byl hedgeový fond, založený v roce 1994.
} 
rozdělena do dvou skupin. CEBS4 definuje tržní riziko likvidity (market liquidity risk) a riziko finanční likvidity (fading liquidity risk).

- Tržní riziko likvidity je riziko, když daná expozice nemůže být uvolněna, uhrazena v krátkém čase bez toho, aby to nemělo významný dopad na tržní cenu. Tento stav je způsoben situací na trhu a jinými faktory, které budou dále uvedeny v článku.

- Riziko finanční likvidity je riziko vycházející z neschopnosti instituce dostat se k svým závazkům a pasivům, které jsou splatné, aniž by se instituce vystavovala neočekávaným ztrátám.

Obě tyto skupiny rizik jsou vzájemně provázány. Když portfolio obsahuje nelikvidní aktivum, které je nutno prodat v krátkodobém horizontu (z důvodu splnění podmínky vzniku rizika likvidity), musí se dané aktivum prodat tzv. pod cenu. Článek se bude zabývat tržním rizikem likvidity, které se dle Bangia et al. (1999) dělí na: exogenní riziko likvidity a endogenní riziko likvidity.

- Exogenní riziko likvidity je dáno externími faktory, a to konkrétně charakteristikou trhu. Riziko souvisí s tržním cenovým rozpětím, tj. rozdílem mezi cenou bid a ask oproti mid (tzv. bid-ask spread). Exogenní riziko je pro každého účastníka stejné a zaleží, zda je trh s danými instrumenty víc likvidní nebo naopak. Např́íklad trh s FX kurzy konkrétně EUR/USD je charakteristický velkým objemem obchodů, stabilním a úzkým spreadem. Náklady na likvidaci jsou zanedbatelné i při vyšších objemech. Naopak trh s FX kurzy rozvojových zemí nebo prašivých bondů (tzv. junk bonds) je nelikvidní a charakteristický vysokou volatilitou bid-ask spreadu s omezenou hloubkou a objemem obchodů.

- Endogenní riziko likvidity je specifické pro konkrétní pozici na trhu, takzvaně je dáno pozicí účastníka na trhu, velikostí expozice obchodu, typem aktiva. Platí pravidlo, čím je větší objem pozice, tím je exogenní riziko likvidity vyšší. Vztah mezi endogenním rizikem likvidity a cenou je znázorněno v následujícím grafu.

\section{Graf 1: Efekt likvidity a velikosti pozice na cenu aktiva}

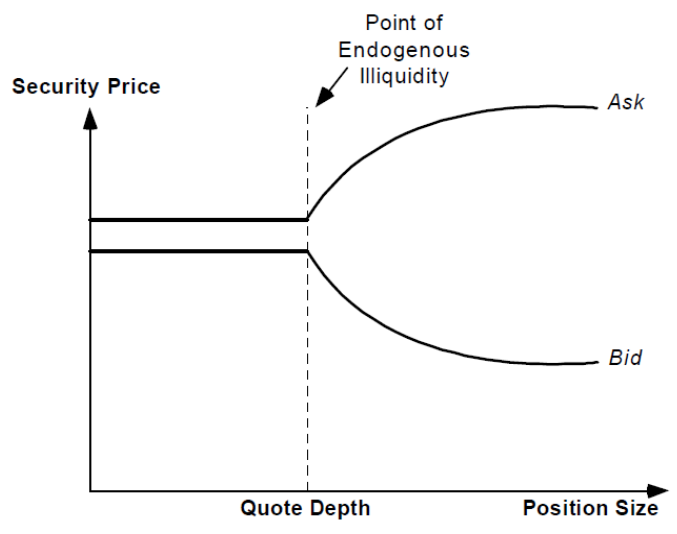

Zdroj: Bangia et al. (1999)

Z grafu 1 vidíme jasný vztah mezi velikostí pozice a cenou. Když pokyn k obchodu nákup/prodej je menšího objemu než objem akceptovaný trhem (Quote Depth) tzv. hloubka

\footnotetext{
${ }^{4}$ Commitee of European Banking Supervisors, Second Part od CEBS's Technical Advice to the European Commission of Liquidity Risk Management (London: CEBS, 2008). Available at www.c-ebs.org
} 
trhu, tak rozdíl mezi nákupní a prodejní cenou je nízký a tzv. spread je zachovaný. V tomto př́padě jsou náklady na likvidaci dané půlkou z bid - ask spreadu, což je dané exogenní rizikem likvidity.

Pokud by obchod převyšoval akceptovatelnou hodnotu, tak by se náklady na likvidaci zvýšily oproti tzv. polovičnímu spreadu ((Cena(ask) - Cena(bid))/2) ${ }^{5}$. Rozdíl mezi celkovými náklady na likvidaci a polovičním spreadem se označuje jako přírůstkové tržní náklady, které jsou způsobené endogenním rizikem likvidity (Bangia et al., 1999). Podle Kyla (1985) je likvidita definovaná:

- Těsností (Tightness), což jsou náklady, dané tržným rozpětím bid-ask spreadu, spojené s okamžitou likvidací relativně malých pozicí.

- Hloubkou (Depth), která popisuje schopnosti investora koupit nebo prodat jakékoliv množství finančních instrumentů bez dodatečných nákladů.

- Pružností (Resiliency), která definuje čas a rychlost, za kterou se cena finančního instrumentu vrátí na svou rovnovážnou hodnotu.

Black (1971) jako čtvrtý aspekt likvidity uvádí bezprostřednost (immediacy), která obsahuje čas potřebný mezi zadáním a uspokojením objednávky investorem.

\section{Možné způsoby zakomponování likvidního rizika do modelu VaR}

Běžný přístup výpočtu VaR od Morgana (1996) se zaměřil na logaritmické změny výnosů z jednotlivých druhů aktiv. Tyto logaritmické změny sloužily jako vstupy pro variačně kovariační metody výpočtu VaR. Existuje několik metod výpočtu hodnot v riziku (VaR), které jsou stručně popsány v první kapitole.

Hlavním problémem základních modelů je použití mid cen pro výnosy, což u nelikvidních trhů a s nelikvidními aktivy v portfoliu může značně podhodnocovat výpočet hodnoty VaR. Zakomponováním likvidního rizika do výpočtu VaR se zpravidla zvýší hodnota VaR oproti klasickým modelům. Dle Bangia et al. (1999) jedním z možných způsobů, jak kvantifikovat tržní likvidní riziko, je výpočet průměrného bid - ask spreadu, relativnímu k mid ceně. V článku budeme předpokládat pouze riziko nákladů vycházejících ze spreadu, tj. rozdílu mezi bid a ask cenou. To znamená, když na trhu dojde k obchodu, který převyšuje akceptovatelnou hodnotu na trhu, objem obchodů se rozloží na více dní tak, aby nedošlo k vlivu endogenního rizika na změnu ceny aktiva nebo portfolia. Obecně reálně existuje vztah mezi cenou a objemem obchodu. Platí, čím vyšší je objem obchodu, tím víc se spread rozšiřuje, co je viditelné i na grafu 1.

Cílem kapitoly není analyzovat všechny přístupy a modely, které se snaží zakomponovat likvidní riziko do modelu VaR, ale poukázat na to, co je základní ideou modelu VaR a jeho upravení o riziko likvidity, které je v praxi dost náročné kvantifikovat. Uvažujeme VaR jednoduchého aktiva, kvantifikací VaR portfolia individuálních aktiv se v důsledku rozsahu článku zabývat nebudeme.

\footnotetext{
${ }^{5}$ pozn. vztah určuje cenu (mid)
} 


\subsection{Zakomponování exogenního rizika do modelu VaR}

Jak jsme si už definovali, exogenní likvidita je daná trhem, to znamená, že náklady likvidace závisí pouze na podmínkách tržního rozpětí, tj. rozdílu mezi nákupní a prodejní cenou vyjadřuje bid - ask spread. Průměr nákupní a prodejní ceny je středová cena, tzv. mid price. Předpokládáme, že ask cena je cena, která je nejnižší možná, za kterou je účastník na trhu ochoten dané aktivum prodat za předem dané množství. Při dokonalém likvidním trhu, jako je standardizovaný trh sakciemi (např. akcie firmy Apple), je bid a ask takměř stejný, to znamená, že spread je blízko nuly. Náklady na likvidaci daného instrumentu jsou nízké, téměř nulové. Náklady na méně likvidním trhu jsou náklady na likvidaci z pohledu prodávajícího v hodnotě polovičního spreadu.

Základní myšlenkou dle autorů (Balgia et al., 1999) je nevyhnutné zakomponování exogenního rizika do $\mathrm{VaR}$ modelu, protože na nelikvidním trhu se výnosy z prodeje aktiv neoceňují cenou (mid), ale cena se upravuje o existující spread, což cenu v př́ípadě prodeje snižuje a naopak v př́ípadě nákupu zase cenu zvyšuje. Platí vztah:

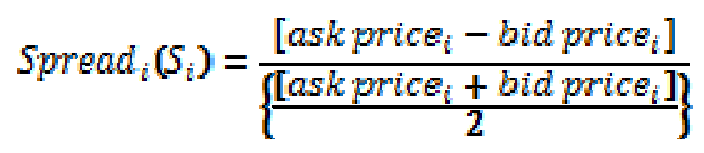

Když platí vztah, že průměr bid a ask ceny je mid price, tak spread můžeme definovat jako:

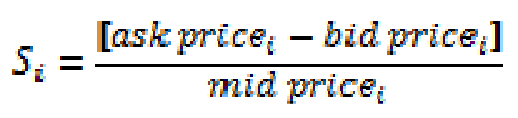

Základním předpokladem je, že místo změn středových cen uvádíme změny nákupních nebo prodejních cen (bid, ask) pozorovaných historicky. Tyto př́růstky lze použít při metodě historických simulací, nebo pomocí nich odhadnout parametry pravděpodobnostního rozdělení. Dle Bangia et al. (1999) je možné uvažovat tržní rozpětí jako samostatnou náhodnou veličinu, která ovlivňuje tržní hodnotu portfolia, a zkoumat tak požadovaný kvantil hodnoty portfolia i se zohledněním měnícího se tržního rozpětí. Při kalkulaci hodnoty v riziku (VaR) v př́ípadě exogenní likvidity budeme nejdřív uvažovat nejhorší denní výnos, který se uvádí jako logaritmus (mid) ceny aktiva $\mathrm{v}$ čase $\mathrm{t}$ a $\mathrm{v}$ čase $\mathrm{t}-1$, který je $\mathrm{v}$ modelu VaR definovaný jako rizikový faktor, u kterého předpokládáme normální rozdělení s očekávanou střední hodnotou výnosů $\mathrm{E}\left(\mathrm{r}_{\mathrm{t}}\right)$ a rozptylem $\boldsymbol{\sigma}_{i}^{\mathbf{z}}$.

$$
r_{t}=\ln \left(\frac{P_{t}}{P_{t-1}}\right) \sim N\left(E\left(r_{t}\right), \sigma_{t}^{2}\right)
$$

Kde $\boldsymbol{P}_{\mathrm{in}}$ je cena i-tého aktiva $\mathrm{v}$ čase $\mathrm{t}, \mathbf{P}_{\mathrm{it}-1}$ je cena i-tého aktiva $\mathrm{v}$ čase $\mathrm{t}-1$, ln je přirozený logaritmus denních změn ceny aktiv. Hodnota v riziku (VaRi) i-tého aktiva při určitém stupni pravděpodobnostního rozdělení (předpokládejme $99 \%$ kvantil rozdělení, což koresponduje s kvantilem normovaného normálního rozdělení 2,33, když zároveň očekávaná hodnota denních výnosu $E\left(r_{t}\right)$ je nula), tak nejhorší možné riziko, což je maximální možná ztráta $\mathrm{z}$ daného aktiva, je dané vztahem:

$$
V u R i=P_{i t}\left(1-e^{\left.E(\mathrm{mt})-2.33 \sigma_{\mathrm{mat}}\right)}\right.
$$

Kde $P_{i t} e^{\mathbf{E}(\mathbf{m})-z_{s} \mathbf{s}-3 \cdot \sigma_{\mathbf{s}}}$ definuje nejhorší možnou cenu aktiva $i$ čase $t . \sigma_{\mathrm{mt}}$ představuje směrodatnou odchylku logaritmických přírůstků tržního faktoru (v našem případě (mid) ceny 
aktiva). $\mathrm{P}$ chápeme jako počáteční hodnotu aktiva. Následně $\mathrm{k}$ maximální možné ztrátě na ceně aktiva musíme přičíst i maximální možný pohyb tržního rozpětí, které definujeme jako transakční náklady na likvidaci. Z předchozích úvah platí, když mid cena je mezi bid a ask cenou, tak náklady na likvidaci expozice jsou dané vztahem:

$$
\frac{\llbracket \text { Nákladynalikvidaci }=\left(P \rrbracket_{i t} S_{i}\right)}{2}
$$

Kde $P_{i t}$ je hodnota i-tého aktiva v čase t, když uvažujeme celé portfolio. Pro zjednodušení uvažujeme jenom jeden druh aktiva. $S_{i t}$ vyjadřuje hodnotu spreadu i-tého aktiva, které se v čase nemění. Následujícím krokem autora, (Bangia et al., 1999) je zakomponování nejhoršího možného pohybu spreadu. Když uvažujeme 5 jako průměrnou hodnotu tržního rozpětí, $P_{t}$ jako mid cenu, $\sigma_{s}$ jako volatilitu spreadu a $\alpha$ je definovaná jako poměr mezi 99 $\%$ kvantilem a směrodatnou odchylkou (u normálního rozdělení je tato konstanta rovna 2,33), tak pro náklady na likvidaci, prŕípadného exogenního rizika likvidace platí:

$$
\text { Näklady vyplyvajici } z \text { exogenniho rizika likvidace }=\frac{P_{t}\left(S+\alpha \sigma_{s}\right)}{2}
$$

V tomto případě předpokládáme normální pravděpodobností rozdělení změn tržního rozpětí, což není v souladu s empirickými daty, hlavně u finančních dat (Bangia et al., 1999). Dle Strnada (2009) výnosy finančního instrumentu se liší a jejich distribuční rozdělení má tlusté konce (fat tails). Jedná se spíše o Studentovo rozdělení nebo jiné např. bimodální (nižší rozpětí jsou typická pro likvidnější trhy). Autor dále uvádí, že problémem představuje nejen volatilita cenových změn, ale také volatilita změn tržního rozpětí se v čase mění. V praxi se tomu říká tzv. volatility clustering. Existují období s vysokou a nízkou volatilitou. Je známé, že v období krize na finančních trzích jsou charakteristické vyšší volatility než ve standardním období. Pomocí exponenciálně vážených průměrů $\left(\mathrm{EWMA}^{6}\right)$ minulých výnosů je možné tento efekt z časti zakomponovat do standartního modelu VAR (Morgan, 1996). Další možnou variantou je použít modely volatility, a to GARCH model (Generalized Autoregresive Conditional Heteroskedasticity) ${ }^{7}$. Když už máme definován odhad nejhoršího pohybu ceny (mid) a nejhoršího pohybu spreadu, můžeme definovat tzv. maximální hodnotu v riziku upravenou o exogenní riziko likvidity, která vyjadřuje nejhorší možnou cenu transakce na druhý den:

$$
P^{*}=P_{i t} e^{-2.3 s \sigma_{m t}}-\frac{P_{i t}\left(S+\alpha \sigma_{s}\right)}{2}
$$

Následně celkový dopad na hodnotu VaR upravený o likvidní riziko by byl definován vztahem:

$$
L A d V a R i=P_{i t}\left(1-e^{\left.-2.38 \sigma_{m}\right)}+\frac{P_{i t}\left(S+\alpha \sigma_{s}\right)}{2}\right.
$$

\footnotetext{
${ }^{6}$ Exponentially Weighted Moving Averages - v tomto případě se přidává váha datům dle jejich minulosti, čím starší data, tím se exponenciálně snižuje jejich váha.

${ }^{7}$ GARCH modely začaly být populární při oceňovaní aktiv (speciálně u opcí), GARCH modely jsou používány k předpovídání volatility finančních náhodných proměnných.
} 
Výpočet hodnoty VaR předpokládá nejhorší hodnotu spreadu, při určitém stupni pravděpodobnosti (v našem případě $99 \%$ ).

\section{Graf 2: Zakomponování likvidního rizika a tržního rizika do VAR (za předpokladu normálního rozdělení)}

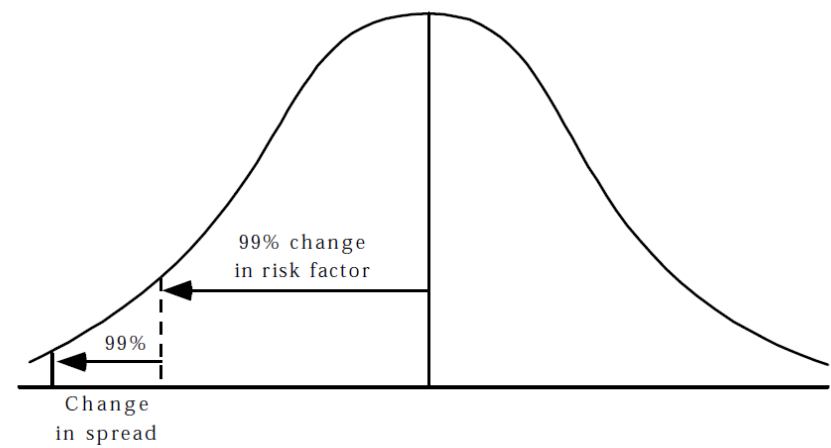

Zdroj: Modeling Liquidity Risk, With Implications for Traditional Market Risk Measurement and Management, Anil Bangia, Til Schuermann, Francis X Diebold,John D. Stroughair, Oliver, Wyman \& Company, December 21, 1999

Když budeme zároveň uvažovat likvidní riziko a tržní riziko při výpočtu VaR, tak hodnota VaR bude vyšší než u VaR, které uvažuje pouze tržní riziko (Bangia et al., 1999) (viz graf 2). Pro zjednodušení autor (Bangia et al., 1999) předpokládá, že likvidní riziko a tržní riziko je pozitivně korelované, to znamená, že v případě extrémních událostí při zvýšení tržního rizika se zvýší i likvidní riziko a naopak. Toto zjednodušení však neplatí v tomto př́ípadě, nebot' korelace mezi pohybem mid ceny a pohybem spreadu nemusí být lineární. Mezi hlavní nedostatky modelu autor uvádí normální rozdělení přírůstků výnosu aktiva a přírůstku spreadu. Zde vzniká úvaha, že hodnota by měla být ohodnocena empiricky na základě historických dat. Dle studie (Bangia et al., 1999) se hodnota $\alpha$ empiricky pohybuje okolo 2 až 4,5. Hodnota $\alpha$ je neznámá a lze ji dle autora Bangia et al.(1999) určit pomocí regrese známých nejhorších relativních spreadů, které jsou určené pomocí historické simulace. Potom daný parametr $\alpha$ může být zakomponován při výpočtu exogenního rizika likvidity (Bangia et al., 1999). V tomto modelu autor ignoruje endogenní likviditu, což je v praxi důležitý faktor, který ovlivňuje náklady likvidace a tím i hodnotu LAdjVaR (Liquidity Adjusted Value at Risk - Hodnota v riziku upravená o likvidní riziko).

\section{Zakomponování exogenního rizika do modelu VaR v případě nenormálního rozdělení}

Další modifikace zakomponování exogenního rizika do modelu VaR je úprava modelu s distribučním rozdělením rozšsiřeného o existenci tlustých konců. Pro mnoho instrumentů, speciálně v rozvojových zemích, je známé, že cenové změny nemají normální rozdělení, tzn., obsahují tlusté konce (Bangia et al., 1999). Formálně se nazývají i leptokurtické. ${ }^{8}$ Platí, když se jedná o normální rozdělení, tak $\theta=1$. Hodnota $\theta$ se zvyšuje v případě odklonu rozdělení od normálního. To znamená, že pravděpodobnost extrémních hodnot je vyšší než u normálního rozdělení.

$$
V a R i=P_{i t}\left(1-e^{\left.\mathrm{E}(\mathbf{r t})-2,33 \theta \sigma_{\mathrm{mit}}\right)}\right.
$$

\footnotetext{
${ }^{8}$ leptokurtická rozdělení jsou rozdělení špičatější okolo středu, přičemž na koncích je jejich hustota vetší a v ramenech menší „užší pás tučné konce“(fat tails)“,
} 
Je známý empirický vztah mezi parametrem $\theta$ a šikmostí $\kappa$ v případě t- rozdělení, a to:

$$
\theta=1.0 .+\phi \ln \left(\frac{\kappa}{3}\right)
$$

Kde $\Phi$ je konstanta, která závisí na pravděpodobnosti existence tlustých konců (např. 1\%, 2,5 $\%$ apod.) a která je odhadnuta pomocí regresní analýzy z rovnice (11) pomocí historické simulace, která neuvažuje normální rozdělení. Z rovnice (12) platí, že když je šikmost rovna 3, tak parametr $\theta$ je rovný 1 . Z uvedených vztahů dle studie (Bangia et al. 1999) vyplývá, že čím je výskyt extrémních hodnot cenových změn na trhu ${ }^{9}$ pravděpodobnější, tím je důležitější zakomponovat faktor distribučního rozdělení $\theta$ do výpočtu VaR upraveného o likvidní riziko. Existuje mnoho dalších přístupů a studií (Al Janabi, 2009) jak zakomponovat likvidní riziko do modelu VaR.

\section{Zakomponování exogenního rizika do modelu VaR v případě vícedenního horizontu likvidace (vícedenní VaR)}

Ve vzorci (10) autor (Bangia et al., 1999) uvažuje o průměrném spreadu a jeho volatilitě, ale neuvažuje o možné variabilitě spreadu přes likvidační období. Další přístup (Al Janabi, 2009) se snaží kvantifikovat náklady na likvidaci během doby likvidace, která je delší než jeden den. Počet dní závisí na zobchodovaném množství za den, což závisí na velikosti expozice a akceptovatelné hranici objemu obchodu, do které se významně neovlivní cena aktiva, takzvaně nepředpokládáme endogenní riziko likvidity. Z následujícího modelu autora (Al Janabi, 2009) vyplývá, že maximální denní ztráta z pozice aktiva $i$ je daná rozptylem nelikvidního aktiva $i$ v čase $t$. Dále platí vztah, že celková vícedenní hodnota v riziku (vícedenní VaR) je daná součtem dílčích ztrát za jednotlivé obchodní dny. Tento model předpokládá, že obchodník může prodávat menší části aktiva z celkové hodnoty aktiva nebo portfolia. $\mathrm{V}$ případě, že rozptyl středové ceny se po dobu likvidace nemění a je roven rozptylu aktiva v prvém dni a když ztráty lineárně klesají každým obchodným dnem, tak rozptyl nelikvidního aktiva po dobu likvidace je určen vztahem:

$$
\begin{gathered}
\sigma_{a d j}^{2}=\left(\left(\frac{\mathrm{t}}{\mathrm{t}}\right)^{2} \sigma_{1}^{2}+\left(\frac{\mathrm{t}-1}{\mathrm{t}}\right)^{2} \sigma_{1}^{2}+\left(\frac{\mathrm{t}-2}{\mathrm{t}}\right)^{2} \sigma_{1}^{2}+\cdots+\left(\frac{3}{\mathrm{t}}\right)^{2} \sigma_{1}^{2}+\left(\frac{2}{\mathrm{t}}\right)^{2} \sigma_{1}^{2}+\left(\frac{1}{\mathrm{t}}\right)^{2} \sigma_{1}^{2}\right) \\
\sigma_{a d j}^{2}=\sigma_{1}^{2}\left(\frac{1}{\mathrm{t}^{2}}\right)\left[(\mathrm{t})^{2}+(\mathrm{t}-1)^{2}+(\mathrm{t}-2)^{2}+.+(3)^{2}+(2)^{2}+(1)^{2}\right] \\
\text { potom } \sigma_{\mathrm{adj}}=\sigma_{1} \sqrt{\frac{(\mathbf{2 t}+1)+(\mathrm{t}+1)}{6 \mathrm{t}}}
\end{gathered}
$$

Kde $t$ je počet obchodních dní potřebných na celkovou likvidaci aktiva $i$, $\sigma_{a \dot{u} j}^{z}$ je rozptyl nelikvidního aktiva $i, \sigma_{\text {adj }}$ je rizikový faktor likvidity, tzv. směrodatná odchylka nelikvidního aktiva $i$. Tento přístup prredpokládá lineární zavírání pozic až pokud se neuzavře celková pozice. Ze vzorce (13) vyplývá, že celkové riziko likvidace se lineárně snižuje s klesajícím počtem obchodných dní, které je závislé na akceptovatelné hranici objemu zobchodované

\footnotetext{
${ }^{9}$ u nelikvidních trhů (např́ílad FX kurzy rozvíjejících se zemí)
} 
pozice, což znamená, že riziko je tomto případě faktorem času. Platí, že se zvyšujícím se počtem $t$ se zvyšuje riziko. Oproti původnímu vzorci (10) neuvažujeme metodu výpočtu EWMA, ale hodnotu relativního VaR dle vzorce (2) a hodnota $\sigma$ je vyjádřená jako $\sigma_{\text {adj,tj. }}$ rizikový faktor likvidity, závislý na počtu dní likvidace $t$.

Dále do původního vzorce (10) zakomponujeme náklady na likvidaci vyplývající ze spreadu $\mathrm{v}$ případě vícedenní likvidace. Nech $\boldsymbol{h}_{i}$ je počet dní likvidace aktiva $i$ a uvažujme, že počet dní likvidace má také vliv na pohyb volatility bid - ask spreadu. Necht' $\sigma_{S i}^{z}$ je denní rozptyl bid - ask spreadu aktiva $i$. Platí, když se mění spread, mění se i náklady na likvidaci po dobu likvidace. Potom můžeme předpokládat, že celkové náklady se rovnají součtu dílčích nákladům za jednotlivé dny. Když předpokládáme, že ztráty a výnosy s měnícího se spreadu jsou nezávislé na době likvidace a jsou nekorelované, tak rozptyl ztrát kvůli měnícímu se bidask spreadu je daný vztahem:

$$
\sigma_{S i}^{2}=\left(\sigma_{S i_{1}}^{2}+\sigma_{S i_{2}}^{2}+\sigma_{S i_{3}}^{2}+\ldots+\sigma_{S i_{k}}^{2}\right)=\sum_{n=1}^{h_{1}} \sigma_{S i_{n}}^{2}
$$

Ve vzorci (16) je předpoklad jako ve vzorci (13). Autor (Al Janabi, 2009) uvažuje, že obchodník likviduje pozice lineárně, až dokud nejsou úplně zlikvidované a rozptyl po dobu likvidace je dán rozptylem prvního dne likvidace, tak platí vztah při horizontu $\mathbf{h}_{\mathbf{i}}$ dní:

$$
\sigma_{S i}^{2}=\left(\left(\frac{1}{\mathbf{h}_{\mathbf{i}}}\right) \sigma_{S i}^{2}+\left(\frac{2}{\mathbf{h}_{\mathbf{i}}}\right) \sigma_{S i}^{2}+\left(\frac{3}{\mathbf{h}_{\mathbf{i}}}\right) \sigma_{S i}^{2}+\ldots+\left(\frac{\mathbf{h}_{\mathbf{i}}}{\mathbf{h}_{\mathbf{i}}}\right) \sigma_{S i}^{2}\right)
$$

Ze vztahu (17) vyplývá, že se zkracující se dobou likvidace se snižuje váha možné ztráty, a tak celkové náklady jsou nižší než náklady bez téhle úvahy. To znamená, že předpokládáme, že obchod nenastane až v poslední den likvidace. Matematicky můžeme vyjádřit vztah (17) následovně:

$$
\sigma_{S i}^{z}=\sigma_{S i_{1}}^{z}\left(\frac{1}{h_{i}\left(1+2+3+\cdots+h_{i}\right)}\right)
$$

Dále ze vztahu (18) vyplývá, že odmocnina rozptylu definuje volatilitu, tzv. směrodatnou odchylku a platí:

$$
\sigma_{S i}=\sigma_{S i_{1}} * \sqrt{\frac{h_{i}+\mathbf{1}}{2}}
$$

Doplněním rovnice (18) a (15) do rovnice $(10)^{10}$ dostaneme celkovou hodnotu vícedenního VaR upraveného o exogenní riziko likvidity v důsledku klesající hodnoty expozice po dobu likvidačního období. Předpokládáme-li, že $\mathrm{t}=\boldsymbol{h i}$, potom platí:

$$
L A d j a R i=(V a R i) \sigma_{2} \sqrt{\frac{(2 \mathrm{t}+1)+(\mathrm{t}+1)}{6 \mathrm{t}}}+\frac{P_{i t}\left(S+\alpha \sigma_{3 i_{1}}+\sqrt{\frac{h_{i}+\mathbf{1}}{2}}\right)}{2}
$$

\footnotetext{
${ }^{10}$ za předpokladu relativního VaR dle vzorce (2) v druhé kapitole
} 
Rovnice (19) udává tzv. percentil rizikového faktoru cenové změny a dynamického rozpětí (spreadu). Rizikový faktor dynamického rozpětí je funkcí počtu dní likvidace a reflektuje stochastické chování bid- ask rozpětí, které je závislé na době likvidace. V tomto př́ípadě je faktor času důležitý. V praxi je sice předpoklad lineární likvidace a měnícího se tržního rozpětí dost silný, ale je blíž reálnému ohodnocení rizika jako klasický VaR, který předpokládá, že celková pozice bude zobchodovaná až poslední den likvidace, jak určuje klasický přístup u vícedenního $\mathrm{VaR}^{11}$. Je jistě zajímavé analyzovat další prrístupy ve kvantifikaci hodnoty $\mathrm{v}$ riziku (VaR) s ohledem na riziko likvidity, především v podmínkách nelikvidních období a trhů a především, když instituce má v portfoliu nelikvidní aktiva.

\section{Závěr}

Riziko tržní likvidity hraje klíčovou roli $\mathrm{v}$ pochopení a kvantifikaci rizika spojeného s obchodováním a jeho nedostatečná kontrola může vést k podkapitalizování finančních institucí. To platí, když portfolia obsahují méně likvidní finanční instrumenty, popř. instrumenty z rozvojových zemí. Přestože není definována standardní technika jak oceňovat riziko tržní likvidity, existuje vícero modelů VaR upravených o likvidní riziko. Za poslední dekádu se tento upravený model stal populárním nástrojem na stanovení tržního a likvidního rizika v modelu VaR. Základní myšlenkou klasického modelu VaR je započítání nákladů na likvidaci obchodovaného instrumentu nebo portfolia za podmínek nepříznivých pohybů tržních sazeb a jejich cen na trhu. Pomocí distribučního rozdělení změn tržních faktorů kvantifikuje jedním číslem maximální možnou ztrátu z expozice za určitý časový horizont s určitým stupněm pravděpodobnosti. Problémem klasického modelu je, že neodděluje riziko tržní likvidy od tržního rizika. Klasický model nezachycuje riziko tržní likvidity, což je základní součástí tržního rizika a přitom tržní riziko a riziko tržní likvidity spolu souvisí. Mimo to se v modelu používají středové ceny (mid ceny), nebo poslední známé tržní ceny a ignoruje se fakt, že likvidace nenastává při průměrné bid- ask ceně, ale ceně snížené o půlku bid- ask spreadu, který se může dokonce měnit během doby likvidace, když je doba likvidace větší než jeden den. Existuje více způsobů kvantifikace, jak hodnoty v riziku (VaR), tak i zohlednění likvidního rizika, které může způsobovat jak endogenní likvidita, tak exogenní likvidita daná podmínkami na trhu.

V článku byl analyzován parametrický způsob výpočtu hodnoty v riziku a zakomponování rizika likvidity jako nákladů na likvidaci konkrétního jednoduchého aktiva. Je třeba poznamenat, že kvantifikace rizika tržní likvidity je rozsáhlejší problematikou a tento článek nezahrnuje všechny aspekty rizika tržní likvidity. Musíme však poznamenat, že nejen v poslední době je vliv rizika tržní likvidity významným faktorem ve výpočtu a kvantifikaci rizik obecně. Cílem článku bylo poukázat na určité základní aspekty rizika tržní likvidity a jeho začlenění do modelu VaR. Také bylo cílem poukázat na význam podhodnocovaní maximální možné ztráty $\mathrm{z}$ investičního instrumentu $\mathrm{v}$ prrípadě nelikvidních trhů nebo zvýšené averze účastníků v období krize kupovat nebo prodávat konkrétní aktivum. Z článku vyplývá, že $\mathrm{v}$ případě nelikvidních aktiv může být hodnota VaR daleko vyšší, což může ovlivnit i naše investiční rozhodování.

\footnotetext{
${ }^{11}$ VaR upraven o vícedenní horizont: Předpokládejme T - denní VaR je rovný vztahu: VaR(1-T) $\sqrt{\mathrm{t}}$
} 


\section{Literatura:}

[1] AL JANABI, M. A. M. Asset Market Liquidity Risk Management: A Generalized Theoretical Modeling Approach for Trading and Fund Management Portfolio.United Arab Emirates University, United Arab Emirates, May 2009.

[2] ARTNER, P., EBER, F., EBER, J. M., HEATH, D. Coherent Measures of Risk. Mathematical Finance, 1999, s. 203-228.

[3] BANGIA, A., DIEBOLD, F. X., SCHUERMANN, T. And STROUGHAIR, J. D. Modeling Liquidity Risk with Implications for Traditional Market Risk Measurement and Management, The Wharton Financial Institutions Center, 1999.

[4] BLACK, F. Towards a Fully Automated Exchange, Part I, Financial Analysts Journal, 27, 1971, s. 29-34.

[5] BOLLERSLEY, T. Generalized Atutoregressive Conditional Heteroskedasticity, In Editor, C. (ed.)Journal of Econometrics 3, North Hollad, 1986, s. 307-3277.

[6] JORION, P. Value at Risk: The New Benchmark for Managing Financial Risk. Second Edition, New York: McGraw - Hill Trade, 2001.

[7] JORION, P. Financial risk management hand book. Sixth Edition, New Jersey: John Wiley \& Son Inc., 2011, 798 s. ISBN: 978-0-470-90401-5.

[8] KYLE, A. Continuous Actions and Insider Trading. Econometrica, 1985, no 6 (November), s. 1315-1335.

[9] MORGAN, J. P. RiskMetrics - Technical Document. Fourth Edition New York, 1996

[10] SECOND PART OF CEBS'S. Technical Advice to the European Commission on Liquidity Risk Management, London: CEBSs, 2008, s. 203-228. www.c-ebs.org.

[11] STRNAD, P. Riziko tržní likvidity a jeho zohlednění v ukazateli value at risk. Praha: Acta Oeconomica Prageensia, 2009.

\section{JEL E42}

\section{Ing. Michal Polák}

Externí doktorand

Katedra bankovnictví a pojišt'ovnictví

Fakulta financí a účetnictví

Vysoká škola ekonomická v Praze

Nám. W. Churchilla 4

13068 Praha - Žižkov

xpolm50@vse.cz 